\title{
Attitudes towards Suicide among Medical and \\ Paramedical Personnel
}

\author{
Dr. P. Krishna Mohan ${ }^{1}$, Dr. Sai Kiran Pasupula ${ }^{2 *}$, Dr. Kodali Madhavi ${ }^{3}$
}

\section{ABSTRACT}

Background: There is an increase in the suicide rate by 43\% in the last three decades (from 1975 to 2005). All the five States viz. Tamil Nadu, West Bengal, Andhra Pradesh, Maharashtra and Karnataka have registered consistently higher number of suicidal deaths during the last few years. Attitude plays a key role in preventing suicide and also providing quality care.

Aim: To assess the attitude towards suicide among medical and paramedical personnel.

Methodology: This study was carried out at Dr. Pinnamaneni Siddhartha Institute of Medical Sciences and Research Foundation (Dr. PSIMS \& RF). Medical professionals and paramedical personnel of our hospital were taken as study group and individuals from general population were taken as the control group. Suicidal attitude questionnaire was employed to measure attitude.

Results: Positive attitude towards suicide was observed more among the medical professionals when compared to paramedical and control groups.

Conclusion: Levels of attitude towards suicide is not similar for each individual and also differs in between the groups .Low levels of positive attitude among paramedical and control group indicates the need to increase awareness of suicide among the general population and paramedical group for prevention of suicides and to provide better care.

Keywords: Suicide, Attitude, Medical personnel, Para medical personnel.

WHO estimates that nearly nine lakh people worldwide die from suicide every year. Attitudes towards suicide are considered to be one of the most important components contributing to variations of suicide rates in different regions or countries. Attitudes towards suicidal patients plays a major role in treating as well as managing suicidal ideations and proper education and training can results in more positive change of attitude ${ }^{[1]}$. The key step in suicide prevention is to modify the attitudes toward suicide via educational efforts and legal levers ${ }^{[2]}$. Regular clinical supervision and ongoing support of budding health professional will definitely ameliorate their worries and difficulties in working with suicide attempters ${ }^{[3]}$.With this background our study

\footnotetext{
${ }^{1}$ M.D, Associate Professor, Department of Psychiatry, Dr. PSIMS \& RF, Gannavaram

${ }^{2}$ M.D , Senior resident, Department of Psychiatry, Guntur Medical college, Guntur

${ }^{3}$ M.D , Assistant Professor, Department of Psychiatry, Dr. PSIMS \& RF, Gannavaram *Corresponding Author

(C) 2015 I K Mohan, S Pasupula, K Madhavi; licensee IJIP. This is an Open Access Research distributed under the terms of the Creative Commons Attribution License (http://creativecommons.org/licenses/by/2.0), which permits unrestricted use, distribution, and reproduction in any Medium, provided the original work is properly cited.
} 
aims to assess and compare the attitude towards suicide among medical and paramedical personnel.

\section{AIMS}

1. To assess the attitude towards suicide among medical and paramedical personnel.

2. To compare the attitude towards suicide among medical and paramedical personnel.

\section{METHODOLOGY}

This study was carried out at Dr. Pinnamaneni Siddhartha Institute of Medical Sciences and Research Foundation on medical professionals and paramedical personnel. Age - Sex matched individuals from general population were taken as the control group. After taking prior consent, suicide opinion questionnaire was employed to measure attitude on all the participants. Statistical analysis was done by using EPI INFO and M.S.Excel software's.

\section{SOQ}

It is a 52-item, self-rated, and 5-point Likert scale which measures suicide attitude on the basis of five factors: Acceptability, perceived factual knowledge, social disintegration, personal defects, and emotional perturbation. Attitudinal statements were scored on a 5-point Likert scale: 1. 'strongly agree', 2. 'agree', 3. 'don't know', 4. 'disagree', and 5. 'strongly disagree'. Scores between 1 and 2.4 were considered 'positive dispositions' or 'favourable attitude', between 2.5 and 3.4 'unsure' or 'uncertain attitude', and 3.5 and above 'negative dispositions' or 'unfavourable attitude'.

\section{ANALYSIS AND RESULTS}

\section{Sociodemographic profile}

As shown in Table 1, total sample consists of ninety participants. A male constitutes forty eight and females constitutes forty two in number. Mean age of participants is 36.5 years.

\section{Table 1:}

\begin{tabular}{|l|l|}
\hline Variable & Value \\
\hline Age : & \\
Mean Age of all the sample & 36.5 \\
Individuals with age range of 25-35 years & 36 \\
Individuals with age range of 35-45 years & 32 \\
Individuals with age range of 45-55 years & 22 \\
\hline Sex : & \\
Male & 48 \\
Female & 42 \\
\hline Marital status & \\
Married & 56 \\
Unmarried & 44 \\
\hline
\end{tabular}




\section{Attitude towards suicide attempters:}

Among total population, most of the individuals had uncertain responses . People shared favourable responses towards eleven items -1,2,4,5,9,14,18,19,38,51,52 . Unfavourable attitude was observed in seven items - 12,23,28,36, 37,40,48. Uncertain responses are observed for the remaining thirty four items.

Individuals among three groups have commonly shared favourable response for three items --

1. Most persons who attempt suicide are lonely and depressed,

2. Most suicides are triggered by arguments with a spouse

19. A rather frequent message in suicide notes is one of unreturned love.

\section{Attitude among Medical group:}

Among medical group favourable attitude was observed for twenty four items $1,4,2,51,19,52,9,10,33,32,6,41,7,25,13,37,24,45,29,43,44,36,40,49$. Unfavourable attitude is observed for 4 items - 11,34,42,46 . Uncertain responses are observed for the remaining twenty four attitudinal statements. Thus individuals have equal number of favourable and uncertain responses.

\section{Attitude among Paramedical group:}

Among paramedical group, favourable attitude is observed for twenty three items $1,2,4,5,9,11,14,16,18,19,20,22,27,31,34,38,39,42,46,47,50,51,52$.unfavourable attitude is observed among 17 items - 49,12,24,48,23,35,28,43,13, 21,26,45,41,30,44,25,40.Uncertain responses are observed for the remaining twelve attitudinal statements. Thus more positive attitude is observed than uncertain or unfavourable attitude.

\section{Attitude among control group:}

Favourable attitude towards suicide was observed for seventeen items $1,2,5,8,9,10,17,19,20,22,29,36,39,40,48,51,52$. Unfavourable attitude is observed for four items $25,28,32,35$. Uncertain responses are observed for the remaining thirty one attitudinal statements .Thus; overall their attitude towards suicide attempters remained uncertain for more than half of the items.

\section{Gender and suicidal attitude:}

Compared to females, males had more favourable attitude for following three items:

5. Most suicide attempts are impulsive in nature . (2.18 \pm 1.19 vs. $2.5 \pm 1.12)$

36. If someone wants to commit suicide, it is their business and 1 we should not interfere (3.5 \pm 1.3 vs. 2.34 ) 
38. Usually, relatives of a suicide victim had no ideas of what was about to happen. (2.08 \pm 0.94 vs. $2.57 \pm 1.06)$.

Females have less favourable responses towards the following items - In times of war, for a captured soldier to commit suicide is an act of heroism ( $2.3 \pm 1.07$ vs. $2.58 \pm 1.23$ ) Once a person survives a suicide attempt, the probability of his trying again is minimal (2.26 \pm 1.08 vs. $2.5 \pm 1.05)$ and the large majority of suicide attempts result in death (3.4 \pm 1.4 vs. $2.97 \pm 1.4)$

Table 2 :

\begin{tabular}{|c|c|c|c|}
\hline Question number & $\begin{array}{l}\text { Mean } \\
\text { medical }\end{array}$ & $\begin{array}{l}\text { Mean } \\
\text { paramedical }\end{array}$ & $\begin{array}{l}\text { Mean } \\
\text { control }\end{array}$ \\
\hline 1. Most persons who attempt suicide are lonely and depressed. & 1.4667 & 1.6 & 2.0667 \\
\hline 2. Most suicides are triggered by arguments with a spouse. & 2.1667 & 2 & 2.3667 \\
\hline $\begin{array}{l}\text { 3. The higher incidence of suicide is due to the lesser influence of } \\
\text { religion. }\end{array}$ & 2.7333 & 2.7 & 2.7667 \\
\hline $\begin{array}{l}\text { 4. I would feel ashamed if a member of my family committed } \\
\text { suicide. }\end{array}$ & 1.5 & 2.1 & 2.9667 \\
\hline 5. Most suicide attempts are impulsive in nature. & 3.2 & 1.4667 & 2.2 \\
\hline $\begin{array}{l}\text { 6. People with incurable diseases should be allowed to commit } \\
\text { suicide in dignified manner }\end{array}$ & 3.6667 & 2.9667 & 2.7 \\
\hline 7. Suicide is an acceptable means to end an incurable illness. & 3.7333 & 3.1667 & 3.0333 \\
\hline 8. People who commit suicide are usually mentally ill. & 3.1 & 2.6667 & 2.2667 \\
\hline 9. Some people commit suicide as an act of self-punishment. & 2.4 & 1.6667 & 1.9667 \\
\hline 10. Suicide is acceptable for aged and infirm persons. & 3.5667 & 2.7667 & 3.7667 \\
\hline $\begin{array}{l}\text { 11. Suicide is clear evidence that man has a basically aggressive } \\
\text { and destructive nature }\end{array}$ & 3.5 & 2.4333 & 2.5667 \\
\hline 12. Suicide happens without warning. & 3 & 1.7667 & 2.7 \\
\hline 13. Most suicide victims are older persons with little to live for. & 3.8 & 2.0667 & 3.1333 \\
\hline $\begin{array}{l}\text { 14. About } 75 \% \text { of those who successfully commit suicide have } \\
\text { attempted suicide at least once before. }\end{array}$ & 2.8667 & 1.7667 & 2.7667 \\
\hline $\begin{array}{l}\text { 15. It's rare for someone who is thinking about suicide to be } \\
\text { dissuaded by a "friendly ear". }\end{array}$ & 2.4 & 2.6667 & 2.7333 \\
\hline $\begin{array}{l}\text { 16. People who commit suicide must have a weak personality } \\
\text { structure. }\end{array}$ & 2.4667 & 2.4667 & 3.4 \\
\hline $\begin{array}{l}\text { 17. Social variables such as overcrowding and increased noise } \\
\text { can lead a person to be more suicide-prone. }\end{array}$ & 3.4333 & 2.9 & 3.7333 \\
\hline $\begin{array}{l}\text { 18. A large percentage of suicide victims come from broken } \\
\text { homes. }\end{array}$ & 2.4667 & 1.4 & 2.6333 \\
\hline $\begin{array}{l}\text { 19. A rather frequent message in suicide notes is one of } \\
\text { unreturned love. }\end{array}$ & 2.2667 & 1.9333 & 2 \\
\hline 20. People who set themselves on fire to call attention to some & 2.7667 & 2.2333 & 2.2333 \\
\hline
\end{tabular}




\begin{tabular}{|c|c|c|c|}
\hline jious issue al & & & \\
\hline $\begin{array}{l}\text { 21. The possibility of committing suicide is greater for older } \\
\text { people (those } 60 \text { and over) than for younger people ( } 20 \text { to } 30 \text { ). }\end{array}$ & 3.4333 & 2.1333 & 3.4 \\
\hline $\begin{array}{l}\text { 22. Most people who commit suicide do not believe in an } \\
\text { afterlife. }\end{array}$ & 3.3667 & 2.2333 & 2.4333 \\
\hline $\begin{array}{l}\text { 23. In times of war, for a captured soldier to commit suicide is an } \\
\text { act of heroism. }\end{array}$ & 2.7667 & 1.9 & 2.7 \\
\hline 24. Once a person is suicidal, he is suicidal forever. & 3.9 & 1.8 & 2.6667 \\
\hline $\begin{array}{l}\text { 25. There may be situations where the only reasonable resolution } \\
\text { is suicide. }\end{array}$ & 3.7667 & 2.3 & 2.3 \\
\hline $\begin{array}{l}\text { 26. Improvement following a suicidal crisis indicates that the risk } \\
\text { is over. }\end{array}$ & 3.2667 & 2.1333 & 2.7667 \\
\hline $\begin{array}{l}\text { 27. Suicides among young people (e.g. college students) are } \\
\text { particularly puzzling since they have everything to live for. }\end{array}$ & 2.9333 & 2 & 2.6667 \\
\hline $\begin{array}{l}\text { 28. Once a person survives a suicide attempt, the probability of } \\
\text { his trying again is minimal. }\end{array}$ & 2.9333 & 2 & 2.2333 \\
\hline 29. Suicide is a normal behaviour. & 3.9667 & 2.5 & 3.6 \\
\hline $\begin{array}{l}\text { 30. Many victims of fatal automobile accidents are actually } \\
\text { unconsciously motivated to commit suicide. }\end{array}$ & 3.2 & 2.2333 & 3.3333 \\
\hline $\begin{array}{l}\text { 31. If a culture were to allow the open expression of feelings like } \\
\text { anger and shame, the suicide rate would decrease substantially. }\end{array}$ & 3.0667 & 1.9 & 2.7 \\
\hline $\begin{array}{l}\text { 32. From an evolutionary point of view, suicide is a natural } \\
\text { means by which the less mentally fit are eliminated. }\end{array}$ & 3.6 & 2.8 & 2.4 \\
\hline $\begin{array}{l}\text { 33. Suicide attempters who use public places (such as a bridge or } \\
\text { tall building) are more interested in getting attention. }\end{array}$ & 3.5667 & 2.6333 & 2.6333 \\
\hline $\begin{array}{l}\text { 34. Suicide rates are a good indicator of the stability of a nation; } \\
\text { that is , the more suicides the more problems a nation is facing. }\end{array}$ & 3.8 & 1.9667 & 2.5667 \\
\hline 35. Sometimes suicide is the only escape from life's problems. & 3.4333 & 1.9333 & 2.4667 \\
\hline $\begin{array}{l}\text { 36. If someone wants to commit suicide, it is their business and } \\
\text { we should not interfere. }\end{array}$ & 4.3 & 2.5667 & 3.7333 \\
\hline $\begin{array}{l}\text { 37. Obese individuals are more likely to commit suicide than } \\
\text { persons of normal weight. }\end{array}$ & 3.8333 & 3 & \begin{tabular}{|l}
3.4667 \\
\end{tabular} \\
\hline $\begin{array}{l}\text { 38. Usually, relatives of a suicide victim had no ideas of what } \\
\text { was about to happen. }\end{array}$ & 2.5333 & 1.8 & 2.6 \\
\hline $\begin{array}{l}\text { 39. Long term self-destructive behaviours, such as alcoholism, } \\
\text { may represent unconscious suicide attempts. }\end{array}$ & 3.2333 & 2 & 2.4667 \\
\hline $\begin{array}{l}\text { 40. We should have "suicide clinics" where people who want to } \\
\text { die could do so in a painless and private manner. }\end{array}$ & 4.3667 & 2.4667 & 3.5667 \\
\hline $\begin{array}{l}\text { 41. Those people who attempt suicide are usually trying to get } \\
\text { sympathy from others. }\end{array}$ & 3.6667 & 2.2 & 3.1 \\
\hline
\end{tabular}




\begin{tabular}{|l|l|l|l|}
\hline 42. People who commit suicide lack solid religious convictions. & 3.5 & 2.1 & 3.3 \\
\hline $\begin{array}{l}\text { 43. Passive suicide, such as an overdose of sleeping pills, is more } \\
\text { acceptable than violent suicide such as by gunshot. }\end{array}$ & 4.1667 & 2.0333 & 2.9667 \\
\hline 44. Suicide occurs only in civilized societies. & 4.2333 & 2.2333 & 2.6333 \\
\hline 45. Most people who commit suicide do not believe in God. & 3.9333 & 2.1667 & 2.9333 \\
\hline $\begin{array}{l}\text { 46. Children from larger families (i.e., three or more children) are } \\
\text { less likely to commit suicide as adults than single or only } \\
\text { children. }\end{array}$ & 3.5667 & 2.3 & 3.2667 \\
\hline $\begin{array}{l}\text { 47. Suicide attempters are, as individuals, more rigid and less } \\
\text { flexible than non-attempters. }\end{array}$ & 3.3333 & 1.9667 & 2.8 \\
\hline $\begin{array}{l}\text { 48. The large majority of suicide attempts result in death. } \\
\text { 49. Some people are better off dead. }\end{array}$ & 2.7667 & 1.8333 & 2.3333 \\
\hline 50. People who attempt suicide are, as a group, less religious. & 3.4333 & 2.1333 & 3.3667 \\
\hline $\begin{array}{l}\text { 51. Those who commit suicide are cowards who cannot face } \\
\text { life's challenges. }\end{array}$ & 2.2 & 1.8333 & 2.9333 \\
\hline $\begin{array}{l}\text { 52. Individuals who are depressed are more likely to commit } \\
\text { suicide. }\end{array}$ & 2.3667 & 1.3667 & 1.8333 \\
\hline
\end{tabular}

\section{DISCUSSION}

Suicide is a complex human behavior as well as multifaceted health problem ${ }^{[1]}$. As both medical as well as paramedical individuals are included in the management of suicidal patients, suicidal attitude of medical and paramedical personals plays a key role in management of suicidal patients. Earlier studies also highlighted the importance of nursing individuals in willingness of help and outcome of suicidal patients ${ }^{[4-5]}$. Attitude towards suicide is variable and proper education with training after assessing the attitude helps the individuals to change the individuals’ attitude more favourable and helps in suicidal prevention.

Earlier studies on suicidal attitude found that several factors such as lack of education and experience of managing patients with self-harm, younger age, and ambivalence towards the clinical population causes uncertain responses towards suicide ${ }^{[6]}$. In our study we found that individuals among the three groups have more uncertain responses than favourable or unfavourable responses. More number of uncertain responses is indicating the need of education and training regarding suicide prevention and management.

According to an Indian study attitude of mental health professionals is more positive when compared to non mental health professionals ${ }^{[7]}$. In the current study, more favourable responses are observed among medical group rather than paramedical or control group which is similar to the findings of earlier study. More education and training towards suicide for medical persons may explain the reason for high favourable responses. 
Among the medical professionals, individuals responded equal number of uncertain and favourable responses. Among the paramedical personal group, individuals responded more favourable responses than uncertain or unfavourable responses.Among the control group , individuals have more uncertain responses than favourable or unfavourable responses.

Regarding the gender and suicidal attitude, Sing Lee etal ${ }^{[8]}$ states that there is not much gender difference towards suicidal attitude which is against to the present study finding. In our study, men had more favourable attitude than women for some attitudinal items, which differs from earlier studies that reported more positive attitudes in female staff. ${ }^{[9,10,11]}$

The influence of age on suicidal attitude is unclear ${ }^{[10]}$. But some studies found that adults have more positive adaptive attitude than younger individuals. In our study, variation of suicide was observed across different age of individuals and more number of favourable responses were observed among the age group of 45-55 years than other age groups.

As the sample recruited for the study is from single institution results cannot be generalised to the whole population is one of the limitation in our study . Personal history of suicide or family history of suicide was not taken into the study which may influences the suicidal attitude .Future research is needed with large sample size at clinical and community level .

The results are concluding that attitude towards suicide is more favourable among medical professionals than paramedical personal or control group Much not favourable among the control group is explaining the low knowledge of the individuals among the normal population . This results shows the need of community programmes to improve the awareness and knowledge regarding the suicide. Proper education regarding the assessment and management of suicide to all medical and paramedical personals at hospital level and Suicidal awareness programmes by Government and other Welfare organisations to common people at community level is required for more favourable attitude among health professionals and non health professionals which helps in proper care and management at hospital level and suicidal prevention at community level.

\section{REFERENCES:}

1. Vijayakumar L. Suicide and its prevention: The urgent need in India. Indian J Psychiatry.2007;49:81-4.

2. Lakshmi Vijayakumar, Indian research on suicide, Indian J Psychiatry. 2010 January; 52(Suppl1): S291-S296.doi: 10.4103/0019-5545.69255PMCID: PMC3146189.

3. Mamta Nebhinani et al ., Nursing students attitude towards suicide attempters : Journal of Neurosciences in rural practice .,DOI : 10.4103/0976-3147.131701

4. Rayner GC, Allen SL, Johnson M. Counter transference and self-injury: A cognitive behavioural cycle. J Adv Nurs. 2005;50:12-9.

5. McLaughlin C. Casualty nurses' attitudes to attempted suicide. J Adv Nurs. 1994;20:1111-8. 
6. McAllister M, Creedy D, Moyle W, Farrugia C. Nurses’ attitudes towards clients who self-harm. J Adv Nurs. 2002;40:578-86.

7. Srivastava M, Tiwari R. A comparative study of attitude of menal health versus nonmental health professionals toward suicide. Indian J Psychol Med. 2012;34:66-9.

8. Sing Lee etal., Attitudes Toward Suicide Among Chinese People in Hong Kong,Suicide and Life-Threatening Behavior 37(5) October 2007 L 2007 The American Association of Suicidology .

9. Anderson M, Standen P, Nazir S, Noon J. Nurses' and doctors' attitudes towards suicidal behaviour in young people. Int J Nurs Stud. 2000;37:1-11.

10. Ghodse AH. The attitudes of casualty staff and ambulance personnel towards patients who take drug overdoses. Soc Sci Med. 1978;12:341-6.

11. Samuelsson M, Asberg M, Gustavsson JP. Attitudes of psychiatric nursing personnel towards patients who have attempted suicide. Acta Psychiatr Scand. 1997;95:222-30. 